\title{
Osmolar Regulation of Endothelin-1 Production by Rat Inner Medullary Collecting Duct
}

\author{
Donald E. Kohan and Eva Padilla \\ Division of Nephrology, Department of Internal Medicine, Veterans Administration Medical \\ Center, and University of Utah School of Medicine, Salt Lake City, Utah 84132
}

\begin{abstract}
Recent evidence has implicated endothelin-1 (ET-1) as an autocrine inhibitor of inner medullary collecting duct (IMCD) sodium and water transport. The regulators of IMCD ET-1 production are, however, largely unknown. Because of the unique hypertonic environment of the IMCD, the effect of varying extracellular tonicity on IMCD ET-1 production was evaluated. Increasing media osmolality from 300 to 450 mosmol with $\mathrm{NaCl}$ or mannitol but not urea caused a marked dose- and timedependent reduction in ET-1 release by and ET-1 mRNA in cultured rat IMCD cells. In contrast, increasing osmolality had no effect on ET-1 production by rat endothelial or mesangial cells. To see if ET-1 varies in a similar manner in vivo, ET-1 production was assessed in volume expanded (lower medullary tonicity) or volume depleted (high medullary tonicity) rats. Urinary ET-1 excretion and inner medulla ET-1 mRNA were significantly reduced in volume depleted as compared to volume expanded animals. These results indicate that extracellular sodium concentration inhibits ET-1 production specifically in IMCD cells. We speculate that extracellular sodium concentration, via regulation of ET-1 production, provides a link between volume status and IMCD sodium and water reabsorption. (J. Clin. Invest. 1993. 91:1235-1240.) Key words: sodium $\bullet$ urea $\bullet$ osmolality $\bullet$ kidney $\bullet$ culture
\end{abstract}

\section{Introduction}

Endothelin-1 (ET-1 $)^{1}$ was originally characterized as a 21 amino acid peptide produced by endothelial cells (1). Subsequent studies have demonstrated that ET-1 is found in the greatest concentration in the inner medulla of the kidney (2). ET-1 in the renal inner medulla, however, has a fundamentally different function than does ET-1 derived from the endothelium. Initial characterization of ET-1 revealed that it caused vasoconstriction (1) and stimulated aldosterone (3) and vasopressin (4) secretion, factors leading to elevated blood pressure

Address correspondence to D. E. Kohan, M.D., Division of Nephrology, University of Utah School of Medicine, Salt Lake City, UT 84132.

Received for publication 7 October 1992 and in revised form 24 November 1992.

1. Abbreviations used in this paper: ET-1, endothelin-1; IMCD, inner medullary collecting duct; TFA, trifluoroacetic acid.

The Journal of Clinical Investigation, Inc.

Volume 91, March 1993, 1235-1240 and salt or water retention. In contrast, ET-1 causes an increase in renal salt and water excretion when infused in doses that have little renal vasoconstrictive effect (5). These latter actions of ET-1 are most likely mediated by the inner medullary collecting duct (IMCD). First, most endothelin receptors in the nephron are located here (6). Second, numerous studies have demonstrated that ET-1 potently inhibits vasopressin-stimulated cAMP accumulation and water transport in IMCD (7, 8 ). Furthermore, ET-1 reduces $\mathrm{Na} / \mathrm{K}$ ATPase activity in the IMCD (9). The reasons why ET-1 should have diametrically opposed physiologic effects in the vasculature as compared to the IMCD are unknown, but may reflect the localized nature of this peptide's actions. Endothelial cell-derived ET-1 is thought to primarily constrict adjacent vascular smooth muscle. Similarly, the ET-1 that modulates IMCD function is most likely derived from local sites. Since the IMCD is the predominant nephron site of ET-1 synthesis (10), it is likely that the IMCD itself is responsible, at least in large part, for producing the ET-1 that regulates its own function. Indeed, recent studies have demonstrated that ET-1 is an autocrine factor in the IMCD (11). Consequently, a novel autocrine system exists in the inner medulla whereby ET-1, produced in large amounts by the IMCD, binds to high density, high affinity receptors (12) on the IMCD with resultant inhibition of sodium and water reabsorption.

Characterization of the factor(s) controlling ET-1 production by the IMCD would provide important insights into the function of this system; however, little is currently known. We have previously shown that several agents that increase ET-1 production by endothelial cells have no effect on ET-1 production by IMCD cells (13). This suggests that ET-1 production by IMCD cells might be regulated by factors unique to this cell type. The environment of the renal inner medulla is unique in that interstitial osmolality varies between 300 and 1,200 mos$\mathrm{mol} / \mathrm{kg} \mathrm{H}_{2} \mathrm{O}$. These high osmolalities are responsible for maintaining a gradient for fluid absorption across the IMCD; increases in inner medullary osmolality occur under conditions favoring sodium and water retention (e.g., dehydration), while decreases in inner medullary osmolality occur under conditions favoring sodium and water loss (e.g., excessive intake of salt and water). Since ET-1 can function in an autocrine manner to modify IMCD sodium and water transport, the possibility exists that one means by which osmolality might regulate IMCD function is through modulation of ET-1 production. Since ET-1 may inhibit sodium and water reabsorption, one would predict that high osmolality in the medulla (as seen in volume depletion) would reduce ET-1 production in the IMCD, thereby enhancing sodium and water retention. Con- 
versely, lower osmolalities (as seen in volume excess) would increase IMCD ET-1 production, causing sodium and water loss. To test this hypothesis, we studied the effects of varying extracellular tonicity on ET-1 synthesis and release by IMCD cells in vitro and in vivo. We report that extracellular sodium concentration controls ET-1 production by this nephron segment, providing a potential link between body volume status and sodium and water excretion.

\section{Methods}

\section{Tissue culture}

IMCD cells. IMCD cells were obtained for culture from male SpragueDawley rats (Sasco, St. Louis, MO) weighing $150-250 \mathrm{~g}$ as previously described (11). Renal papillae were minced and incubated in $4 \mathrm{ml}$ $0.1 \%$ collagenase A (Boehringer Mannheim, Indianapolis, IN) and $0.01 \%$ deoxyribonuclease (type I; Sigma Immunochemicals, St. Louis, MO) in Krebs buffer (118 mM NaCl, $14 \mathrm{mM}$ glucose, $25 \mathrm{mM}$ $\mathrm{NaHCO}_{3}, 4.7 \mathrm{mM} \mathrm{KCl}, 2.5 \mathrm{mM} \mathrm{CaCl}, 1.8 \mathrm{mM} \mathrm{MgSO}_{4}, 1.8 \mathrm{mM}$ $\mathrm{KH}_{2} \mathrm{PO}_{4}$ ) for $120-150 \mathrm{~min}$ at $37^{\circ} \mathrm{C}$. During the last hour, the cells were aspirated up and down in a pipette 5-7 times every $15 \mathrm{~min}$. When a suspension of small clumps of cells and individual tubules was attained, the mixture was filtered through a 37- $\mu \mathrm{m}$ mesh membrane. 6 $\mathrm{ml}$ of sterile water was added to the filtrate, a procedure shown to disrupt all cells except those of the collecting duct (11). The cells were washed in PBS containing 10\% albumin and centrifuged (Histopaque1077; Sigma Immunochemicals) to remove cell debris. Intact cells were washed and suspended in modified medium $\mathrm{Kl}$ (10) (50:50 DMEM/F 12 containing $5 \mu \mathrm{g} / \mathrm{ml}$ insulin, $5 \mu \mathrm{g} / \mathrm{ml}$ transferrin, $5 \mathrm{ng} / \mathrm{ml}$ selenium, $50 \mathrm{nM}$ hydrocortisone, and $10 \% \mathrm{FCS}$ ). The cells were placed into the top chamber of 13-mm inserts (Millicell-CM; Millipore Corp., Bedford, MA) previously coated with collagen (see below) to give $\sim 350,000-500,000$ cells per insert. The inserts were placed into a 24-well culture dish and the wells filled with media to cover the bottom of the inserts. The cells were grown to confluence $(\sim 3-4 \mathrm{~d})$ at $37^{\circ} \mathrm{C}$ in a $5 \% \mathrm{CO}_{2}$ incubator.

Semipermeable membranes were prepared by adding $138 \mu \mathrm{l}$ of a solution of $0.15 \mathrm{mg} / \mathrm{ml}$ rat tail collagen (type 1; Boehringer Mannheim) to the upper surface of 13-mm Millicell-CM inserts and allowing the collagen to dry overnight. $1 \mathrm{~h}$ before addition of the cells, $60 \mu \mathrm{l}$ of FCS was added to the upper surface of the inserts, allowed to sit for 30 $\mathrm{min}$, and then aspirated off. This latter procedure markedly enhanced attachment of cells to the membrane.

Mesangial cells. Mesangial cells were isolated from rats as previously described (11). Briefly, glomeruli were obtained using 60,100 , and 200 mesh sieves, incubated in $750 \mathrm{U} / \mathrm{ml}$ collagenase (type IV; Worthington Biochemical Corp., Freehold, $\mathrm{NJ}$ ) and $0.01 \%$ deoxyribonuclease (type I; Sigma Immunochemicals) for $30 \mathrm{~min}$ at $37^{\circ} \mathrm{C}$. Digested glomeruli were washed twice and cultured in RPMI 1640 containing $20 \%$ bovine calf serum and insulin $(0.5 \mathrm{U} / \mathrm{ml})$ at $37^{\circ} \mathrm{C}$ in a $5 \%$ $\mathrm{CO}_{2}$ incubator. Cultures were used between passages 5-10.

Endothelial cells. Rat pulmonary endothelial cells were a generous gift from Dr. John Michael, University of Utah. The characteristics of these cells have been extensively described (14).

Immunofluorescence. Confluent IMCD monolayers were examined for the presence of endothelial cells with anti-Factor VIII-related antigen antibody. Monolayers were fixed in ice-cold methanol and then placed onto coverslips. The cells were incubated with $20 \%$ goat serum (Sigma Immunochemicals) for $10 \mathrm{~min}$, washed in PBS, and rabbit anti-human anti-factor VIII-related antigen antibody ( $1: 20$ dilution in $20 \%$ goat serum) (Accurate Chem. \& Sci. Corp., Westbury, NY) added for $30 \mathrm{~min}$. The cells were washed extensively in PBS and incubated in FITC-goat anti-rabbit IgG (1:10 dilution in 20\% goat serum) for $30 \mathrm{~min}$. After final washing in PBS for $15 \mathrm{~min}$, the coverslips were mounted on glass slides and observed for fluorescence using a fluorescent microscope (Carl Zeiss, Inc., Thornwood, NY). Rat pulmo- nary endothelial cells were stained in an identical manner and served as positive controls.

Determination of effect of osmolality on ET-1 release. Confluent monolayers of IMCD cells were rinsed twice with DME without phenol red containing $10 \mathrm{mM}$ Hepes, $5 \mu \mathrm{g} / \mathrm{ml}$ insulin, $5 \mu \mathrm{g} / \mathrm{ml}$ transferrin and $5 \mathrm{ng} / \mathrm{ml}$ selenium (phenol red-free DME). Selenium alone or containing various amounts of added $\mathrm{NaCl}$, urea, or mannitol was added to both apical and basolateral sides of the monolayer and incubated for $1-24 \mathrm{~h}$ at $37^{\circ} \mathrm{C}$ in a $5 \% \mathrm{CO}_{2}$ incubator. Apical and basolateral media were combined and processed as described by Sugiura et al. (15). The media was mixed with $1 / 10$ vol of $5 \%$ BSA and $1 / 40$ vol of $0.4 \%$ Triton $\mathrm{X}-305$. The media was applied to a cartridge (Bond Elut $\mathrm{C}_{8}$ Analytichem Int., Harbor City, CA ) prewashed successively with $100 \%$ acetonitrile $/ 0.1 \%$ trifluoroacetic acid (TFA), $100 \%$ methanol (MeOH) $/ 0.1 \%$ TFA, and $0.1 \%$ TFA. After applying the sample, the column was washed with $0.1 \%$ TFA and $40 \% \mathrm{MeOH} / 0.1 \%$ TFA and endothelin eluted with $70 \% \mathrm{MeOH} / 0.1 \%$ TFA $/ 0.01 \%$ Triton X-305. The eluate was concentrated (Speed Vac; Savant, Farmingdale, NY) and suspended in RIA buffer. This procedure resulted in recovery of $82 \pm 6$ ( $n$ $=5)$ of $128 \mathrm{pg}$ and $87 \pm 5 \%(n=5)$ of $8 \mathrm{pg}$ of ET-1 standards added to 1 $\mathrm{ml}$ of incubation media.

ET-1 was measured using a kit purchased from Peninsula Laboratories, Inc. (Belmont, CA) and as previously described by this laboratory (10). The lower limit of sensitivity for ET-1 detection was $2 \mathrm{pg}$. Intraassay variation was $<9 \%$; interassay variation was $<15 \%$. Competitive binding inhibition curves for ET- 1 antibody showed $<5 \%$ cross-reactivity with unlabeled ET- 3 and $<3 \%$ cross-reactivity with unlabeled ET2. Reactivity with big endothelin has not been evaluated.

The insert containing the cell monolayer was placed into $0.1 \mathrm{~N}$ $\mathrm{NaOH}$. An aliquot was mixed with Bradford reagent (Bio-Rad Laboratories, Richmond, CA) and protein concentration determined by measuring absorbance at $590 \mathrm{~nm}$ ( 10). All results are expressed as pg ET-1/ mg protein.

Determination of effect of osmolality on ET-1 mRNA. Traditional Northern analysis and RNase protection assays were not sensitive enough to detect ET-1 mRNA under all conditions studied, hence a quantitative PCR method was used as previously described (16). Cultured IMCD cells previously exposed to varying osmolalities were overlaid with $4 \mathrm{M}$ guanidinium thiocyanate, $25 \mathrm{mM}$ sodium citrate, $1 \%$ $\beta$-mercaptoethanol, and $1 \%$ sarcosyl ( $\mathrm{pH} 7.0$ ). After homogenization, each sample was subjected to cesium chloride density gradient centrifugation. The RNA pellet was washed in 70\% ethanol, chloroform extracted, and ethanol precipitated. The integrity of each RNA sample was verified by agarose/formaldehyde gel electrophoresis and quantified spectrophotometrically. $2.5 \mu \mathrm{g}$ of total RNA from each sample was reverse transcribed by incubating with $100 \mathrm{pmol} / \mu$ l random hexamers (Boehringer Mannheim), $4 \mathrm{mM} \mathrm{MgCl}, 10 \mathrm{U} / \mu$ l murine Moloney leukemia virus reverse transcriptase (Gibco Laboratories, Grand Island, NY), $2 \mathrm{U} / \mathrm{ml}$ RNAsin (Promega Corp., Madison, WI), $500 \mu \mathrm{M}$ deoxynucleotide triphosphates (dNTP; The Perkin-Elmer Corp., Norwalk, CT), $1 \mathrm{mM}$ DTT, $50 \mathrm{mM} \mathrm{KCl}, 10 \mathrm{mM}$ Tris-Cl, and $0.01 \%$ gelatin (final buffer $\mathrm{pH} \mathrm{8.3)} \mathrm{for} 1 \mathrm{~h}$ at $37^{\circ} \mathrm{C}$. The reverse transcriptase was inactivated by heating for $5 \mathrm{~min}$ at $95^{\circ} \mathrm{C}$. The resultant $\mathrm{cDNA}$ was amplified by PCR. Each sample was measured for ET-1 and $\beta$-actin cDNA in separate tubes using specific primers. The upstream and downstream primers for ET-1 were GCCAAGCAGACAAAGAACTCCGAG and GCTCTGTAGTCAATGTGCTCGGTT, respectively. These yielded a single 247-bp fragment. The sequence for the 247-bp fragment was analyzed by Margaret Robinson in Dr. Ray White's laboratory at the University of Utah using cycle sequencing with fluoresceinated primer ends. Analysis of the sequence revealed that it was identical to position 371-618 in rat ET-1 cDNA (17). PCR of rat genomic DNA yielded a 1,300-bp product, indicating that these primers spanned an intron. The upstream and downstream primers for $\beta$-actin were TGGAGAAGAGCTATGAGCTGCCTG and GTGCCACCAGACAGCACTGTGTTG, respectively, which yielded a 201-bp cDNA fragment. PCR of genomic DNA yielded a 289-bp product that is complementary to position $2499-2788$ in the $\beta$-actin gene, confirming that this primer set also spans an intron. PCR was performed by incubating 
$5 \mu \mathrm{l}(\sim 0.25 \mu \mathrm{g})$ of sample cDNA with $50 \mathrm{mM} \mathrm{KCl}, 10 \mathrm{mM}$ Tris-Cl, $0.01 \%$ gelatin, $1.5 \mathrm{mM} \mathrm{MgCl}_{2}, 2.5 \%$ formamide, $2 \mathrm{U}$ Taq polymerase (Boehringer Mannheim), $200 \mu \mathrm{M}$ dNTP, 100 pmol of B-actin or ET-1 primers, and $1 \mu \mathrm{Ci}\left[{ }^{32} \mathrm{P}\right] \mathrm{dCTP}$ (Amersham Corp., Arlington Heights, IL) in $50 \mu \mathrm{l}$ final volume (final pH 8.3 at room temperature). PCR using $\beta$-actin primers was carried out for $25 \operatorname{cycles}\left(15 \mathrm{~s}\right.$ at $94^{\circ} \mathrm{C}, 15 \mathrm{~s}$ at $65^{\circ} \mathrm{C}, 30 \mathrm{~s}$ at $\left.72^{\circ} \mathrm{C}\right)(9600 \mathrm{Gene}-\mathrm{Amp}$ System; Perkin-Elmer Cetus Instruments, Norwalk, CT). PCR using ET-1 primers was carried out for 30 cycles under identical conditions. ET- 1 and $\beta$-actin primers were never combined in the same tube. $20 \mu$ l of the final PCR reaction was electrophoresed on an $8 \%$ acrylamide (20:1 acrylamide/bis-acrylamide ) gel containing $1 \mu \mathrm{g} / \mathrm{ml}$ ethidium bromide. The bands corresponding to the cDNA product were excised, mixed with scintillation cocktail, and cpm determined on a beta counter (Beckman Instruments, Fullerton, CA).

ET- 1 and $\beta$-actin cDNA obtained from PCR of reverse transcribed RNA were used to generate standard curves. The cDNA was amplified by PCR, the resultant amplified product divided into small fractions that were, in turn, reamplified. After removal of primers (Magic PCR Prep; Promega Corp.), the purity of the final product was confirmed by electrophoresis. At the end of the purification, the amount of standard cDNA was quantitated spectrophotometrically. Standard curves for $\beta$-actin or ET-1 were made by simultaneously amplifying sample cDNA and, in separate tubes, standard cDNA $\left(10^{-1}-10^{-7} \mathrm{ng} /\right.$ tube $)$. Every PCR amplification included a standard curve. All PCR consisted of simultaneous amplification (in separate tubes) of cDNA for ET-1 and $\beta$-actin. All results are expressed as ag ET- $1 \mathrm{cDNA} / \mathrm{pg} \beta$-actin cDNA to control for the amount of RNA initially reverse transcribed. The accuracy of this quantitative PCR technique has been previously described (16). In brief, three separate reverse transcriptions of the same RNA sample, followed by PCR of the resultant cDNA (using the same ET-1 and B-actin standard curves), yielded only a 5\% and a 3\% variability in measured ET-1 and B-actin CDNA, respectively; the ratio of ET-1 to B-actin cDNA varied by $4 \%$. In the second control, the reproducibility of quantitation of cDNA was evaluated. Three separate PCR amplifications, each using independently made standard curves, were performed on the same sample of cDNA. The calculated amount of ET-1 and B-actin cDNA varied by $15 \%$ and $11.5 \%$, respectively, while the ratio of ET-1 to B-actin cDNA varied by $9 \%$. Standard curves using $0.1-100 \mathrm{pg}$ of $\beta$-actin cDNA (which encompasses all sample values) gave correlation coefficients invariably $>0.99$. Similarly, standard curves using 0.1-100 fg of ET-1 cDNA (which encompasses all sample values) gave correlation coefficients invariably $>0.98$.

In vivo studies. Male Sprague-Dawley rats weighing $175-200 \mathrm{~g}$ were volume expanded ( $3 \mathrm{~d}$ of drinking $0.9 \% \mathrm{NaCl}$ ) or depleted ( $1 \mathrm{~d}$ of water deprivation). A 24-h urine sample was collected under oil on the day before death and urinary volume, urine sodium concentration and urine osmolality measured by the Clinical Chemistry laboratory at the University of Utah. Urinary ET-1 concentration was measured as described above. Animals were then sacrificed by ether inhalation, serum was collected for determination of ET-1 concentration, and the renal cortex and papilla were excised and snap frozen. Frozen tissue was placed into $4 \mathrm{M}$ guanidinium thiocyanate, $25 \mathrm{mM}$ sodium citrate, and $1 \% \beta$-mercaptoethanol and immediately homogenized. RNA was purified and ET- 1 and $\beta$-actin mRNA quantitated as described above.

Statistics. All data were compared by analysis of variance. Results are expressed as mean \pm SEM. $P$ values $<0.05$ were taken as significant.

Materials. All chemicals and reagents were obtained from Sigma Immunochemicals, unless otherwise stated.

\section{Results}

Cell culture. To examine the regulation of IMCD ET-1 production, it was necessary to develop a purified population of IMCD cells that produced enough ET-1 to be readily measured by radioimmunoassay. We chose to study primary cultures of IMCD cells, since these cells release abundant amounts of ET-1 into the bathing media. These cultures contained only the typical epithelial cell cobblestone pattern was apparent. No cells contained large lipid droplets characteristic of interstitial cells. IMCD monolayers were completely negative for Factor VIIIrelated antigen immunofluorescence; $95 \%$ of endothelial cells were brightly positive.

Effect of osmolality on ET-1 production by IMCD cells. To assess the effect of osmolality on IMCD viability, media tonicity was increased with $\mathrm{NaCl}$ from 300 to 1,200 mosmol/liter for $6 \mathrm{~h}$ in confluent IMCD cultures. Osmolalities less than 600 mosmol/liter had no effect on ${ }^{51} \mathrm{Cr}$ release, trypan blue staining, cell number, or cell protein while osmolalities greater than $600 \mathrm{mosmol} /$ liter significantly increased ${ }^{51} \mathrm{Cr}$ release. In addition, increasing media tonicity to 600 or $900 \mathrm{mosmol} /$ liter with $\mathrm{NaCl}$ for $6 \mathrm{~h}$ reduced IMCD transepithelial electrical resistance to $42.6 \pm 1 \%$ or $26.3 \pm 1.3 \%$, respectively, of the resistance in the same wells just before addition of hypertonic media (initial resistance $325 \pm 12 \Omega / \mathrm{cm}^{2} ; P<0.001, n=6$ each group). Conversely, raising the media tonicity to 450 mosmol with $\mathrm{NaCl}$ did not significantly alter transepithelial electrical resistance $(91 \pm 5.9 \%$ of control, $n=6)$. All subsequent studies were done, therefore, at maximal osmolalities of $450 \mathrm{mosmol} /$ liter. Increasing media osmolality to $450 \mathrm{mosmol} /$ liter with $\mathrm{NaCl}$ resulted in a pronounced time-dependent decrease in IMCD immunoreactive ET-1 release (Fig. $1 A$ ). This effect of hypertonic $\mathrm{NaCl}$ on ET-1 release was largely reversible: ET-1 release increased from $27 \pm 6 \%$ of control (after $6 \mathrm{~h}$ in $450 \mathrm{mosmol} /$ liter media) to $82 \pm 2 \%$ of control ( $12 \mathrm{~h}$ after return to normal media, $n=3$ each group). Raising media osmolality to 450 mosmol/liter with $\mathrm{NaCl}$ resulted in a similar time-course of reduction of ET-1 mRNA levels in IMCD cells (Fig. $1 B$ ), indicating that the reduction in ET-1 release is largely caused by reduced mRNA.

It is possible that the effect of hypertonic $\mathrm{NaCl}$ on ET-1 production is caused by phenotypic alterations that occurred in culture. To evaluate this possibility, freshly isolated rat IMCD cells were exposed to control ( $300 \mathrm{mosmol} / \mathrm{liter})$ or 450

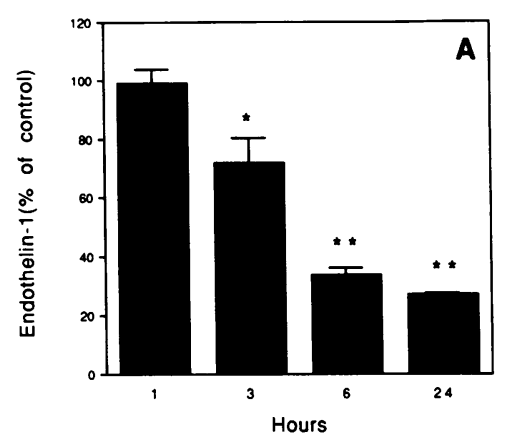

Figure 1. Effect of osmolality on IMCD cell immunoreactive ET-1 release $(A)$ and ET-1 mRNA $(B)$. Confluent cultures of IMCD cells were exposed to media at an osmolality of 300 or $450 \mathrm{mosmol} / \mathrm{liter}$ ( $\mathrm{NaCl}$ added) for 1-24 h. All values in $A$ are expressed as pg ET-1 released $/ \mu \mathrm{g}$ total protein by cells exposed to

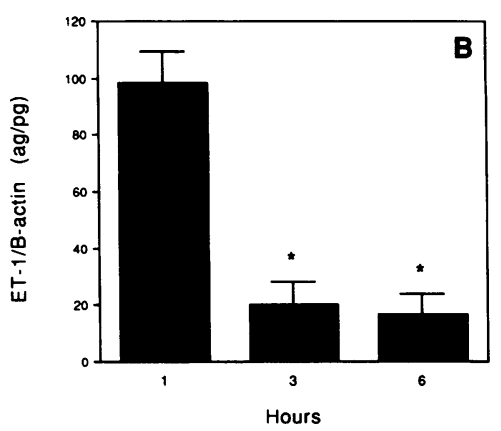
$450 \mathrm{mosmol} / \mathrm{liter} \mathrm{me}$ dia as a percentage of $\mathrm{pg}$ ET-1 released $/ \mu$ g cell in cells exposed to 300 mosmol/liter media. All results in $B$ are expressed as atograms (ag) ET-1 cDNA/pg $\beta$-actin cDNA. For all data, $n=3$ each data point; ${ }^{*} P<0.025,{ }^{* *} P$ $<0.001$. 
mosmol/liter (with $\mathrm{NaCl}$ ) media. As before, hypertonic $\mathrm{NaCl}$ caused a significant reduction in IMCD ET-1 release $(49 \pm 12 \%$ of control, $n=6, P<0.005$ ), confirming that this phenotype is preserved in the culture process.

The reduction in ET-1 production may have been caused by acute changes in osmolality, perhaps as part of the cell's early volume regulatory response. To assess this possibility, IMCD cells were grown from the time of initial plating until confluence $(\sim 72-96 \mathrm{~h})$ in media at a tonicity of 300 or 450 mosmol/liter (made hypertonic with $\mathrm{NaCl}$ ). Confluent cultures grown in $450 \mathrm{mosmol} /$ liter released only $34.1 \pm 8.9 \%$ of the ET-1 released by cells grown in 300 mosmol/liter (control $=258 \pm 92 \mathrm{pg} \mathrm{ET}-1 / \mu \mathrm{g}$ protein per $6 \mathrm{~h} ; n=6$ each group, $P$ $<0.001)$. These results indicate, therefore, that the reduction in $\mathrm{ET}-1$ production caused by hypertonic $\mathrm{NaCl}$ persists for several days and is not caused by factors associated with acutely changing extracellular tonicity.

To determine if hypertonic inhibition of ET-1 production is a generalized property of cells producing the peptide, rat mesangial and endothelial cells were exposed to elevated media $\mathrm{NaCl}$ concentrations. Increasing media $\mathrm{NaCl}$ to give final osmolalities of 350,400 , and $450 \mathrm{mosmol} /$ liter for $6 \mathrm{~h}$ resulted in a marked dose-dependent reduction of IMCD ET-1 release; however, it had no effect on ET-1 release by mesangial or endothelial cells in culture (Fig. 2). Hence, hyperosmolality-induced inhibition of ET-1 production is not a general characteristic of cells synthesizing ET-1 and suggests that IMCD ET-1 production is under unique regulation.

Sodium and chloride are the major solutes in the inner medulla that increase tonicity (18). Urea is also found in high concentrations in the inner medulla, however, because of its ability to rapidly permeate cell membranes, urea does not contribute significantly to interstitial tonicity and resultant changes in cell volume (18). To determine how hypertonic $\mathrm{NaCl}$ reduces IMCD ET- 1 production, media osmolality was increased with either $\mathrm{NaCl}$, urea, or mannitol (which, like $\mathrm{NaCl}$, does not enter the cell). Increasing media osmolality with either mannitol or $\mathrm{NaCl}$ caused a similar dose-dependent reduction in ET-1 release (Fig. 3 ). In contrast, increasing media osmolality with urea had a much smaller effect on ET-1

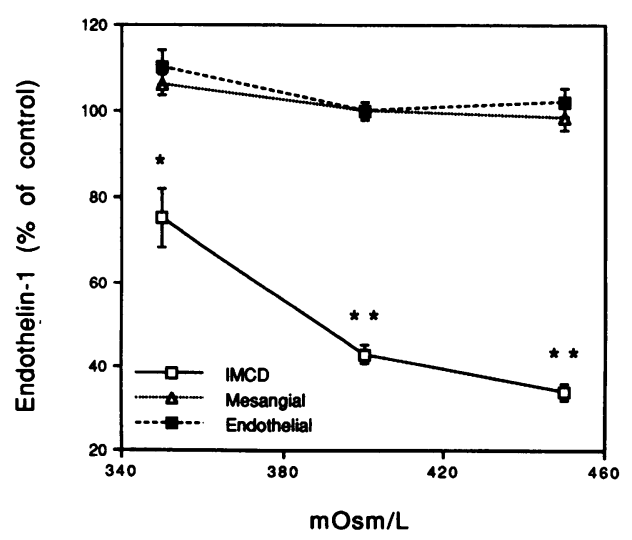

Figure 2. Effect of increasing media osmolality with $\mathrm{NaCl}$ on ET-1 release by rat IMCD, mesangial, and endothelial cells. Cells were incubated for $6 \mathrm{~h}$ with $300,350,400$ or $450 \mathrm{mosmol} / \mathrm{liter}$ media and ET-1 release and cell protein measured. All results are expressed as percent of control ( 300 mosmol/liter). $n=4$ each data point; ${ }^{*} P$ $<0.025,{ }^{* *} P<0.001$ vs control.

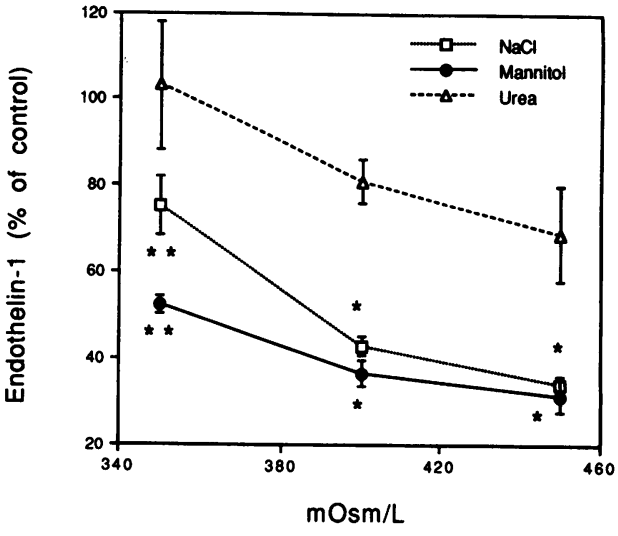

Figure 3. Effect of increasing media osmolality with $\mathrm{NaCl}$, mannitol or urea on ET-1 release by IMCD cells. Cells were incubated for 6 $h$ with $300,350,400$ or 450 mosmol/liter media and ET-1 release and cell protein measured. All results are expressed as percent of control ( $300 \mathrm{mosmol} /$ liter $) . n=3-4$ each data point; ${ }^{* *} P<0.025$, ${ }^{*} P<0.001$ vs control.

production (Fig. 3). These data suggest that the reduction in ET-1 release by IMCD cells is caused by factors associated with cell shrinkage rather than the osmolality of the surrounding fluid.

In vivo studies. As discussed above, hypertonic inhibition of ET-1 production could provide a mechanism by which volume status could regulate IMCD sodium and water excretion. According to this prediction, volume depletion, which leads to a rise in inner medulla sodium concentration, should reduce IMCD ET-1 production. Conversely, volume expansion, which reduces inner medulla sodium concentration, should increase IMCD ET-1 production. To test this hypothesis, rats were either volume depleted (deprived of drinking water for 1 d) or volume expanded (given $0.9 \% \mathrm{NaCl}$ to drink for $3 \mathrm{~d}$ ). As expected (18), urine osmolality and urine sodium concentration were markedly elevated in the dehydrated, as compared to the volume expanded, group (Table I). The elevation in urine sodium concentration accounted for approximately one quarter of the rise in urine osmolality; the rest of the difference was likely caused by urea (18). Despite a tendency for serum ET-1 levels to be higher in the volume-depleted animals, urinary ET-1 excretion was much lower in this group (Table I). Since urinary ET-1 excretion reflects renal tubule production of ET-1 (19), these data suggest that volume depletion is associated with reduced nephron ET-1 production. To evaluate IMCD ET-1 synthesis, ET-1 mRNA was quantitated. Originally, we had wanted to directly measure ET-1 mRNA in isolated tubule segments. This technique, however, involves removal of the tubule from its in vivo environment and could potentially confuse changes that occurred in vivo. In addition, techniques using in situ hybridization of ET-1 mRNA or immunostaining for cell-associated ET-1 would not be likely to be sensitive enough to detect significant differences in the already small amounts of mRNA or peptide made by these cells. Consequently, ET-1 mRNA was measured in snap-frozen inner medulla and, as a control, renal cortex. ET-1 mRNA was slightly, but significantly, lower in the cortex of salt-loaded as compared to dehydrated rats (Fig. 4), perhaps reflecting a tendency for decreased serum levels of ET-1 in this group. In contrast, ET-1 mRNA was significantly higher in the inner me- 
Table I. Effect of Water Deprivation or Sodium Chloride Loading on Renal Function and ET-I Levels in Serum and Urine

\begin{tabular}{lllccrr}
\hline & $\mathrm{U}_{\mathrm{Na}}$ & \multicolumn{1}{c}{$\mathrm{U}_{\text {osm }}$} & $\mathrm{U}_{\mathrm{Na}} \mathrm{V}$ & $\mathrm{V}$ & Serum ET-1 & Urine ET-1 \\
\hline & meq/liter & mosmol/liter & $\mu e q / d$ & $m l / d$ & $p g / m l$ & $p g / d$ \\
Dehydration & $373 \pm 89$ & $3804 \pm 432$ & $161 \pm 43$ & $0.5 \pm 0.1$ & $2.12 \pm 0.39$ & $5.5 \pm 1.9$ \\
NaCl load & $105 \pm 11^{\ddagger}$ & $1642 \pm 173^{*}$ & $1432 \pm 230^{*}$ & $13.2 \pm 2.8^{*}$ & $1.75 \pm 0.33$ & $40.2 \pm 5.5^{*}$ \\
\hline
\end{tabular}

Rats were volume expanded ( $3 \mathrm{~d}$ of $0.9 \%$ saline to drink) or depleted ( $1 \mathrm{~d}$ without water). A 24-h urine sample was collected on the day before death and urinary volume $(\mathrm{V})$, urine sodium concentration $\left(\mathrm{U}_{\mathrm{Na}}\right)$, urine osmolality $\left(\mathrm{U}_{\text {osm }}\right)$, sodium excretion $\left(\mathrm{U}_{\mathrm{Na}} \mathrm{V}\right)$, and ET-1 excretion were measured. $n=6$ each group; ${ }^{*} P<0.001$ vs dehydration, ${ }^{\ddagger} P<0.05$ vs. dehydration.

dulla of salt-loaded as compared to dehydrated rats (Fig. 4). Since osmolality does not appear to affect endothelial cell ET-1 production, and since the IMCD is the only other major component of the inner medulla known to make ET-1 (10), these data suggest that the decrease in inner medulla ET-1 mRNA in dehydration reflects lower IMCD mRNA levels.

\section{Discussion}

These studies demonstrate that increases in extracellular tonicity result in decreased ET- 1 production by cultured IMCD cells. Since sodium is the predominant impermeant solute in the inner medulla, it is reasonable to assume that if this system is operative in vivo, then interstitial sodium concentration regulates ET-1 production by the IMCD. The finding that inner medullary ET-1 mRNA and urinary ET-1 excretion are reduced in the setting of high medullary tonicity supports the hypothesis that extracellular tonicity regulates ET-1 production by the IMCD.

Why an autocrine pathway for regulation of salt and water transport exists in the IMCD is unknown. Taken together, these in vivo and in vitro studies provide an important clue as to the purpose of this system. It has been recognized that renal medullary blood flow rises during conditions associated with sodium and water loading and falls during volume depletion (20). Elevated medullary blood flow would act to "wash out" solutes, thereby lowering medullary tonicity, while decrements in medullary blood flow would act in the opposite direction to raise medullary tonicity (20). Hence, by responding to inner medullary sodium concentration, ET- 1 could then signal the IMCD to appropriately retain or lose sodium and water as the body volume status demands. Such a concept of osmotic regula-

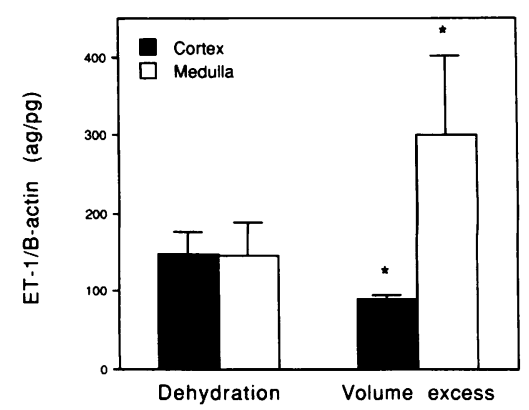

Figure 4. Effect of dehydration or volume excess on ET-1 mRNA in renal cortex and inner medulla. Animals were volume depleted or expanded as described in the text, followed by extraction of RNA from snap-frozen cortex and inner medulla. Cortex and inner medulla were obtained

from the same rats to facilitate comparison of relative ET-1 mRNA levels. $n=3$ each data point; ${ }^{*} P<0.05$ as compared to dehydrated animals. tion of collecting duct water transport is supported by previous studies demonstrating augmentation of vasopressin-induced cAMP accumulation in the IMCD by hypertonicity $(21,22)$. It is conceivable that ET-1 plays a role in this enhancement of vasopressin responsiveness: Hypertonicity would reduce IMCD production of ET-1 and decrease tonic inhibition of vasopressin action. Studies designed to test this hypothesis are needed.

Osmotic regulation of ET-1 synthesis and actions in the inner medulla has been examined in preliminary studies. Hyperosmolality has been demonstrated to reduce ET-1 binding to interstitial cells in the inner medulla (23), providing another mechanism by which increased tonicity could reduce ET-1 actions. In contrast, in another preliminary study, it was noted that increasing media osmolality to $600 \mathrm{mosmol} /$ liter with $\mathrm{NaCl}$, mannitol, or urea resulted in stimulation of ET- $1 \mathrm{immu}-$ nostaining of IMCD cells in culture (24). It is not certain, however, that immunostaining accurately reflects ET-1 production. Furthermore, since immunostaining was the only parameter evaluated, the significance of these preliminary observations is unclear. Another study has evaluated the renal response to an intravenous infusion of antiendothelin antiserum (25). These investigators found that animals on a low sodium but not a high sodium diet increased sodium excretion when given antiendothelin antiserum. Since IMCD ET-1 production would be expected to be relatively low on a low sodium diet, these results can not be explained by alterations in IMCD ET-1 actions. On the contrary, plasma renin activity, which was markedly elevated in animals on a low sodium diet, was reduced by ET-1 antiserum. This could easily result in a reduction in plasma aldosterone and reduced distal nephron sodium transport. These results, therefore, underscore the differences between the endocrine and circulatory effects of ET-1 and its actions in the IMCD. The challenge remains to design studies that can clearly delineate the separate function of these ET-1 systems.

The reason why hypertonicity reduces ET-1 release by IMCD cells, but not by endothelial or mesangial cells, is unknown. Clearly, factors must exist in the IMCD that allow this cell type to respond in a unique way to changes in environmental tonicity. Several possibilities exist as to the nature of these hypertonicity-responsive factors. First, a number of mechanisms have been identified by which tonicity might regulate gene transcription, including alterations in DNA supercoiling (26) and intracellular potassium concentration (27). Hypertonicity may also modify mRNA translation by stabilizing untranslated RNA secondary structure (28). These systems have, however, only been clearly identified in bacteria $(26,27)$ or in cells transfected with simian virus 40 -based plasmids (28). 
IMCD cells have been shown to increase aldose reductase and betaine transporter gene transcription in response to hypertonicity, an effect that correlates with the sum. of intracellular sodium plus potassium concentration (29). Since the effects of hypertonicity on ET-1 production are present in IMCD cells, but not in endothelial or mesangial cells, identification of an element specific to IMCD cells that interacts with the ET-1 promoter or ET-1 mRNA may be possible. Identification of such an element may provide new insights into how tonicity regulates gene expression.

In summary, this study demonstrates osmotic regulation of ET-1 production by the IMCD. The possibility is raised that such regulation provides a link between body volume status and collecting duct sodium and water reabsorption. Finally, to our knowledge, this study represents the first demonstration of a potential physiologic role for osmotic regulation of an autocrine peptide system.

\section{Acknowledgments}

The authors gratefully acknowledge the technical help of Alisa Hughes.

This work was supported in part by Merit Review and Career Development Awards from the Department of Veterans Affairs and by $\mathrm{Na}$ tional Institutes of Health grant DK-44440 (all to D. E. Kohan).

\section{References}

1. Yanagisawa, M., H. Kurihara, S. Kimura, Y. Tomobe, M. Kobayashi, Y. Mitsui, Y. Yazaki, K. Goto, and T. Masaki. 1988. A novel potent vasoconstrictor peptide produced by vascular endothelial cells. Nature (Lond.). 332:411-415.

2. Kitamura, K., T. Tanaka, J. Kato, T. Eto, and K. Tanaka. 1989. Regional distribution of immunoreactive endothelin in porcine tissue: abundance in inner medulla of the kidney. Biochem. Biophys. Res. Commun. 161:348-352.

3. Cozza, E. N., C. E. Gomez-Sanchez, M. F. Foecking, and S. Chiou. 1989. Endothelin binding to cultured calf adrenal zona glomerulosa cells and stimulation of aldosterone secretion. J. Clin. Invest. 84:1032-1035.

4. Yoshizawa, T., O. Shinmi, A. Giaid, M. Yanagisawa, S. J. Gibson, S. Kimura, U. Uchiyama, J. M. Polak, T. Masaki, and I. Kanazawa. 1990. Endothelin: a novel peptide in the posterior pituitary system. Nature (Lond.). 247:462464.

5. Denton, K. M., and W. P. Anderson. 1990. Vascular actions of endothelin in the rabbit kidney. Clin. Exp. Pharmacol. Physiol. 17:861-872.

6. Terada, Y., K. Tomita, H. Nonoguchi, and F. Marumo. 1992. Different localization of two types of endothelin receptor mRNA in microdissected rat nephron segments using reverse transcription and polymerase chain reaction. $J$. Clin. Invest. 60:107-112.

7. Tomita, K., H. Nonoguchi, and F. Marumo. 1990. Effects of endothelin on peptide-dependent cyclic adenosine monophosphate accumulation along the nephron segments of the rat. J. Clin. Invest. 85:2014-2018.

8. Oishi, R., H. Nonoguchi, K. Tomita, and F. Marumo. 1991. Endothelin-1 inhibits AVP-stimulated osmotic water permeability in rat inner medullary collecting duct. Am. J. Physiol. 261:F951-F956.

9. Zeidel, M. L., H. R. Brady, B. C. Kone, S. R. Gullans, and B. M. Brenner. 1989. Endothelin, a peptide inhibitor of $\mathrm{Na}^{+}-\mathrm{K}^{+}$-ATPase in intact renal tubular epithelial cells. Am. J. Physiol. 257:C1101-C1107.

10. Kohan, D. E. 1991. Endothelin synthesis by rabbit renal tubule cells. Am. J. Physiol. 261:F221-F226.

11. Kohan, D. E., and E. Padilla. 1992. Endothelin-1 is an autocrine factor in the rat inner medullary collecting duct. Am. J. Physiol. In press.

12. Kohan, D. E., A. K. Hughes, and S. L. Perkins. 1992. Characterization of endothelin receptors in the inner medullary collecting duct of the rat. J. Biol. Chem. 267:12336-12340.

13. Kohan, D. E., and F. T. Fiedorek, Jr. 1991. Endothelin synthesis by rat inner medullary collecting duct cells. J. Am. Soc. Nephrol. 2:150-155.

14. Ryan, U. S., and L. White. 1986. Microvascular endothelium isolation with microcarriers: arterial, venous. J. Tissue Cult. Methods. 10:9-13.

15. Sugiura, M., T. Inagami, and V. Kon. 1989. Endotoxin stimulates endothelinc--release in vivo and in vitro as determined by radioimmunoassay. Biochem. Biophys. Res. Commun. 161:1220-1227.

16. Hughes, A. K., R. C. Cline, and D. E. Kohan. 1992. Alterations in renal endothelin-1 levels in spontaneously hypertensive rats. Hypertension. In press.

17. Sakurai, T., M. Yanagisawa, A. Inoue, U. S. Ryan, S. Kimura, Y. Mitsui, K. Goto, and T. Masaki. 1991. cDNA cloning, sequence analysis and tissue distribution of rat preproendothelin-1 mRNA. Biochem. Biophys. Res. Commun. 175:44-47.

18. Bulger, R. E. 1987. Composition of renal medullary tissue. Kidney Int. 31:556-561.

19. Abassi, Z. A., J. E. Tate, E. Golumb, and H. R. Keiser. 1992. Role of neutral endopeptidase in the metabolism of endothelin. Hypertension (Dallas). 20:89-95.

20. Chiou, S.-Y., J. G. Porush, and P. F. Faubert. 1990. Renal medullary circulation: hormonal control. Kidney Int. 37:1-13.

21. Sato, M., and M. J. Dunn. 1986. Osmolality, vasopressin-stimulated cAMP, and $\mathrm{PGE}_{2}$ synthesis in rat collecting tubule cells. Am. J. Physiol. 250:F802-F810.

22. Ishikawa, S., T. Saito, and T. Kusuya. 1985. Role of osmolality in an antagonism of prostaglandin E on vasopressin-induced cellular cAMP in the cultured rat renal papillary collecting tubule cells. Biomed. Res. 6:269-274.

23. Hollander, A., B. M. Wilkes, D. Hart, E. Girardi, and E. P. Nord. 1991. Hyperosmolality inhibits endothelin receptor binding and post receptor signaling in rat medullary interstitial cells. J. Am. Soc. Nephrol. 2:472. (Abstr.)

24. Hart, D., M. S. Goligorsky, and E. P. Nord. 1991. Osmolar regulation of endothelin-1 synthesis by rat inner medullary collecting duct cells in primary culture. J. Am. Soc. Nephrol. 2:402. (Abstr.)

25. Yamada, K., and S. Yoshida. 1991. Role of endogenous endothelin on renal function in rats. Am. J. Physiol. 260:F34-F38.

26. Higgins, C. F., C. J. Dorman, D. A. Stirling, L. Waddell, I. R. Booth, G. May, and E. Bremer. 1988. A physiologic role for DNA supercoiling in the osmotic regulation of gene expression in S. typhimurium and E. Coli. Cell. 52:569584.

27. Ramirez, R. M., W. S. Prince, E. Bremer, and M. Villarejo. 1989. In vitro reconstitution of osmoregulated expression of proU of Escherichia coli. Proc. Natl. Acad. Sci. USA. 86:1153-1157.

28. Kozak, M. 1988. Leader length and secondary structure modulate mRNA function under conditions of stress. Mol. Cell. Biol. 8:2737-2744.

29. Burg, M. B., and A. Garcia-Perez. 1992. How tonicity regulates gene expression. J. Am. Soc. Nephrol. 3:121-127. 